\title{
ФРАЗЕОЛОГІЗМ ЯК ОБ'СКТ ВИВЧЕННЯ В ІНШОМОВНІЙ АУДИТОРІї (доцільність використання й критерії добирання)
}

\author{
МАРІЯ СЦІРА \\ Львівський національний університет імені Івана Франка, Львів - Україна \\ pisarmaria@gmail.com; ORCID: 0000-0003-1977-4383

\section{FRAZEOLOGIA JAKO PRZEDMIOT NAUCZANIA W AUDYTORIUM OBCOJEZZYCZNYM (celowość zastosowania i kryteria doboru)}

\section{MARIJA SCIRA}

Lwowski Narodowy Uniwersytet imienia Iwana Franka, Lwów — Ukraina

STRESZCZENIE. Artykuł dotyczy problematyki definicji frazeologii oraz klasyfikacji frazeologizmów. Badanie koncentruje się na zasadach nauczania frazeologii w audytorium obcojęzycznym. Celem artykułu jest wytyczenie kryteriów doboru jednostek frazeologicznych do ich zastosowania w procesie nauczania języka ukraińskiego jako obcego w audytorium obcojęzycznym. Przedstawiono zasady prezentacji frazeologizmów w audytorium obcojęzycznym, określono kryteria doboru jednostek frazeologicznych dla studentów obcojęzycznych na poziomie początkowym, takie jak: prosta struktura frazeologiczna (wyrazy w sensie dosłownym, 2-3 elementy, prosta struktura morfemiczna); przejrzysta forma wewnętrzna (motywacja); aspekt badań regionalnych; częstotliwość użycia frazeologizmu. W procesie nauczania nauczyciel musi stworzyć potencjał językowy i komunikacyjny, który przede wszystkim zwiększy zdolność studenta do skutecznego postrzegania i przyswajania informacji. Nauczanie języków powinno stanowić część składową kulturowo-narodowego postrzegania nowego środowiska. Tylko wówczas bowiem student obcojęzyczny uzyskuje świadomość językową, która ułatwi mu postrzeganie formuł językowych na tle ogólnej kulturowo-narodowej specyfiki.

Słowa kluczowe: frazeologia, nauka języka ukraińskiego jako obcego, kulturowo-narodowa specyfika, kryteria, studenci obcojęzyczni 


\title{
FRAZEOLOGY AS THE OBJECT OF STUDY IN FOREIGN AUDIENCE (expediency and selection criteria)
}

\author{
MARIIA STSIRA \\ Lviv Ivan Franko National University, Lviv — Ukraine
}

\begin{abstract}
The article deals with the issues of the definition of phraseology, classification of phraseologisms, and focuses on the principles of teaching phraseologisms for foreigners. The purpose of the article is to show the criteria of selection of phraseological units for their application in the process of studying Ukrainian as a foreign language, to describe the principles of presenting phraseologisms for a foreign language audience. The criteria of selecting phraseological units for foreign students at the initial level are set out, namely: a simple structure of phraseology (words in the literal sense, 2-3 components, a simple morphemic structure); transparent internal form (motivation); regional studies aspect; frequent use of phraseologism. In the process of learning, the teacher is to form a linguistic and communicative potential, which, first of all, will increase the student's ability to effectively perceive and master information. Language teaching should form general cultural and national component of the perception of the new environment, since in this way a foreign student forms a linguistic consciousness that facilitates the perception of language formulas against the background of common cultural and national peculiarities.
\end{abstract}

Key words: phraseology, learning Ukrainian as a foreign language, specificity, criteria, foreign students

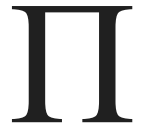

остулат В. фон Гумбольдта про те, що „різні мови — це не стільки різне позначення однієї й тієї самої речі, скільки різне ії бачення" [Гумбольдт 1985: 347] (переклад автор. - М. С.), став основним принципом методики викладання мови як іноземної. Іншим важливим іiі постулатом є те, що мова - засіб вираження мислення людини, специфічне відображення світу. Завдяки мові відбувається передавання інформації про традиції, життя, історію країни кожного етносу.

Загальновідомо, що фразеологізми вербалізують почуття, думки, мовленнєві якості людини, надають їм специфічного національного відтінку. Фразеологічні одиниці належать до особливого національно маркованого складу мови. Національний колорит у фразеологізмах створюється їхнім історичним та етноситуативним мотивуванням, лінгвокраїнознавчим тлом, лексичними компонентами та структурою [див.: Ажнюк 1984: 61].

Зв'язок української мови, яку вивчає студент як іноземну, і мислення, сформованого рідною мовою, безперечно, існує й проявляється в тому, що новий спосіб мислення формується засобами української мови через набуття 
нового життєвого або фахового, теоретичного або практичного досвіду сучасної реальності [див. про це: Селівестрова 2007: 9].

В українському мовознавстві $є$ низка грунтовних досліджень, у яких висвітлено суттєві питання класифікації фразеологізмів, їхньої структури, семантики, стилістики, перспективи розвитку фразеологічних одиниць у мові, їхнього застосування з навчальною метою, зокрема в навчанні української мови як іноземної.

В українській лінгводидактиці проблемам залучення фразеології до процесу навчання й вивчення української мови як іноземної присвячено багато праць, зокрема Л. Селівестрова [Селівестрова 2007: 9] та М. Шклярська [Шклярська 2012: 251] зосереджують увагу на проблемах методики засвоєння фразеологізмів в іншомовній аудиторії, методах навчання цьому. Зауважмо, що Л. Селівестрова виокремлює лінгвістичний, психологічний та методологічний компоненти навчання, наголошує на врахуванні психологічного фактора під час вивчення мови. Адже психологія допомагає визначити, які якості людини домінують у певний період іiі навчання i, відповідно, потребують обов'язкового врахування [Селівестрова 2007: 10]. Г. Кузь та Н. Ядловська акцентують на проблемах використання фразеологізмів у підручниках для іноземців. Г. Кузь розглядає дидактичні прийоми семантизування та засвоєння фразеологізмів, специфіку їхньої репрезентації в підручниках, досліджує критерії відбирання фразеологічного матеріалу для використання в навчальному процесі [Кузь 2016: 88]. Н. Ядловська пише про вивчення фразеологізмів на різних етапах вивчення іноземної мови [Ядловська 2007: 122]. Н. Скиба в статті Формування комунікативної компетенції у студентів-іноземиів на фразеологічному рівні наголошує на формуванні в студентів-іноземців комунікативної компетенції й зауважує, що іноземець часто не розуміє такого художнього прийому, як авторська іронія, оскільки усталені вирази переважно пишуть без лапок. Щоб зрозуміти подібні конструкції (напр., недовго музичка грала) потрібні певні фонові знання [Скиба 2012: 271]. На думку Г. Філь, національно-культурний компонент фразеологічних одиниць української мови відображає трудову діяльність, політичний устрій, явища традиційного побутового характеру, реалії дійсності [Філь 2012: 268].

Мета цієї статті - схарактеризувати критерії відбирання фразеологічних одиниць для їхнього застосування в процесі вивчення української мови як іноземної, описати принципи подання фразеологізмів в іншомовній аудиторії.

Неможливо вивчити іноземну мову, не знаючи менталітету, уявлень, поглядів індивідів, особливостей культури, способу життя, національних традицій. Вирішальний вплив на відмінність національних картин світу справляє національна ментальність, що притаманна певній етнокультурній спільноті. Ментальність - одна з форм суспільної свідомості, що закріплена в матеріа- 
лізованих речах, але має несвідомий характер, відповідну структуру, виражену у взаємозв'язках внутрішніх рис.

Фразеологічна одиниця є одним з основних складників мовної картини світу. Кожна людина по-своєму уявляє світ, тому об'єктивну реальність можна назвати образом мовної картини світу. Завдяки знакам, символам мова відображає культуру народу від покоління до покоління. Вірування, традиції, ментальність $є$ специфічними рисами носіїв мови, і вони відображаються у фразеологізмах.

В енциклопедії української мови зазначено, що фразеологізм, фразеологічна одиниця, фразеологічний зворот, фразема - це „нарізно оформлений, але семантично цілісний і синтаксично неподільний мовний знак, який своїм виникненням і функціонуванням зобов'язаний фраземотворчій взаємодії одиниць лексичного, морфологічного та синтаксичних рівнів" [Українська мова: Енциклопедія 2004: 770].

Студенти-іноземці повинні не тільки правильно засвоїти звуковий та графічний склад фразеологічних одиниць, але й сформувати у свідомості нове поняття, щоб адекватно користуватися цією фразеологічною одиницею. Фразеологічна одиниця виступає в кожному випадку як готова формула. Вона протиставляється в мові та мовленні тим одиницям, які мовці створюють у процесі комунікації за відомими зразками й за певними правилами. Особливості значення багатьох фразеологізмів не можна, напр., зрозуміти й пояснити, спираючись тільки на значення компонентів, що входять до складу фразеологічних одиниць. Це, безперечно, не означає, що в семантиці фразеологізму не можуть бути відбиті певні зміни. Важливо зіставити їх зі значеннями відповідних словосполучень-прототипів й із ситуаціями, що привели до формування нового значення. Утворившись унаслідок багаторазового вживання в людському колективі в тій чи тій виробничій галузі, усталені вирази поступово розширювали свої функції, набували нового змісту.

У навчанні української мови як іноземної перед викладачем рано чи пізно постає питання щодо введення до словника іноземних студентів фразеологічних одиниць. На думку Г. Кузь, важливими для відбирання фразеологічного мінімуму до словника студентів-іноземців $є$ такі критерії: лінгво-країнознавча та комунікативна цінність, доступність, нормативність, пов'язаність із граматичним i лексичним мінімумами, можливість витлумачити фразему стисло й знайомими словами, прозора внутрішня форма, наявність відповідника в рідній мові, екзотичність, орієнтація на сучасну дійсність. На різних рівнях вивчення мови шкала важливості названих критеріїв буде різною. Напр., на початковому та базовому рівнях (A1-A2) основними є принципи доступності, прозорості внутрішньої форми, комунікативної цінності, можливість одним-двома словами витлумачити значення, “інтернаціональність” фраземи. На середньому рівні (B1-B2) 
важливо брати до уваги лінгвокраїнознавчий потенціал фразеологічних одиниць, їхню екзотичність, пов'язаність із граматичним та лексичним мінімумами. На високому рівні $(\mathrm{C} 1-\mathrm{C} 2)$ необхідно доповнювати лексичний і граматичний матеріал різностильовими фраземами, сучасними новотворами, поширеними в 3МІ та науковому стилі [Кузь 2013: 128]. Отже, вивчення фразеології - це найвищий рівень оволодіння мовленням.

Звичайно, “фразеологічна” вправність не є визначальною у вмінні послуговуватися українською мовою як іноземною, особливо на ранніх етапах iii вивчення. Реалізовувати свої побутові та освітні (чи інші) потреби іноземний студент може й без використання фразеологічних одиниць. Однак мовне середовище, у якому перебуває студент, зрештою “влаштує зустріч” із фразеологічним фондом української мови.

Якщо йдеться про засвоєння комунікативно-поняттєвого мінімуму, напр., на початковому рівні, то насамперед необхідно запропонувати для вивчення найбільш поширені формули привітання, прощання, побажання, вибачення, подяки тощо (Привіт! Добрий день! До побачення! Добраніч! До зустрічі! Гарних вихідних! Дякую! Будь ласка! Прошу! Вибачте!). А на наступних етапах можна включати використовувані рідше - 3 нагоди відповідних релігійних свят чи в інших ситуаціях (Христос народився! - Славімо Його! Христос воскрес! - Воістину воскрес! Дай, Боже, щуастя! - Дякую. Дай, Боже, вам!). Узагальнюючи думки дослідників щодо можливості використання фразеологічних одиниць під час вивчення української мови як іноземної, Ю. Сагата зауважує, що запорукою ефективності засвоєння пропонованого на заняттях фразеологічного матеріалу є його впорядкованість [Сагата 2009: 157-171]. Фразеологізми, з якими іноземець стикається на занятті, мають бути не випадковими, а пов'язаними з лексико-комунікативною темою. Це дасть змогу полегшити й зробити більш ефективним процес розуміння, запам'ятовування та практичного застосування вивчених ідіом у звичних для студентів ситуаціях. Студенти будують свої висловлювання на визначену тему в певній комунікативній ситуації, використовуючи вже засвоєний не тільки лексичний, а й фразеологічний матеріал, при цьому значно збагачуючи своє мовлення та одночасно запам'ятовуючи фразеологізми.

Значну групу становлять фразеологізми, що фіксують морально-етичні оцінки (душа в душу; брати близько до серия), а також фразеологізми, що відображають психолого-етнографічні ознаки, зокрема риси характеру, особливості реагування на різні обставини життя (кров з молоком; ні риба ні м'ясо; майстер на всі руки).

Спробуймо пояснити деякі з них.

Кров з молоком - 'рожевовидий, рум'яний, здоровий (про людину та їі обличчя)' [Фразеологічний словник української мови 1999, 1: 399]. На заняттях $з$ української мови студенти-іноземці вивчають тему "Портрет люди- 
ни”, під час якого одне із завдань - описати зовнішність людини, застосовуючи слова здоровий, рум'яний, високий, худий та ін. Тож доцільно пояснити іноземним слухачам, що людська кров червоного кольору, а якщо ії змішати з білим молоком, то рідина буде рожевою.

Майстер на всі руки - 'людина, яка все вміє робити, вправна, тямуща у всякому ділі' [Фразеологічний словник української мови 1999, 1: 460]. На початковому етапі надто складно пояснити зміст наведеного фразеологізму таким тлумаченням. Уважаємо, що слід спрощено розкрити значення цієї фраземи, застосовуючи слова, які студенти вже засвоїли. Отже, майстер на всі руки - це 'людина, яка має багато вмінь, усе робить добре'. Наголосімо, що в процесі вивчення іменників студенти можуть утворити форму множини від слова рука.

Іншим типом стійких сполучень, які доречно використовувати вже на початкових етапах (особливо в навчанні мови студентів, які знають хоча б одну слов'янську мову), можуть бути усталені порівняння, що мають здебільшого прозору мотивацію і є нескладними для сприйняття: бути на сьомому небi; як риба у воді; як без рук; вітер у голові; прикусити язика.

Розгляньмо фразеологізм як риба у воді - 'почуватися вільно, невимушено, добре' [Фразеологічний словник української мови 1999, 2: 736]. У процесі навчання студенти ознайомилися з лексичними значеннями слів риба, вода, добре. Вони розуміють, що рибі у воді добре, бо це ії природне середовище, так само, як і людині в сприятливих життєвих умовах. Використовуємо принцип пояснення нового через відоме.

Уважаємо легкими для студентів-іноземців прості за будовою й прозорі за внутрішньою формою стійкі сполучення, напр.: права рука; давати слово; набрати в рот води; знати як свої п'ять пальців; бути на коні; як кіт наплакав; бити чолом; яблуку ніде впасти; або все, або нічого; їхати зайцем. Лінгвокраїнознавчий критерій під час добирання таких фразеологізмів відступає на другий план, основними натомість $€$ прозора внутрішня форма та проста будова, наявність відповідника в рідній мові [Фразеологічний словник української мови 1999, 1: 125].

Розгляньмо значення фразеологізму набрати в рот води - 'утратити здатність або бажання говорити; затято мовчати' [Фразеологічний словник української мови 1999, 1: 518]. Найкраще, як видається, пояснити зміст одиниці візуально: запропонувати студентам випити ковток води та й при цьому спробувати щось сказати. Вони не зможуть говорити й легко запам'ятають цей фразеологізм.

Бити чолом - 'шанобливо вклонятися, вітаючи кого-небудь' [Фразеологічний словник української мови 1999, 1: 26]. Найлегше роз'яснити зміст фраземи - продемонструвати самим викладачем легкий уклін студентам. Однак легкий уклін під час вітання або прощання 3 іншою особою $\epsilon$ 
невербальною формою етикету, ознакою гарної культури поведінки, поваги та ввічливості. Але потрібно зважати на особливості культури, носіями якої $\epsilon$ іноземці, адже вони ці норми можуть по-іншому сприйняти або ж у їхній країні такого немає.

Права рука - 'перший помічник, довірена особа у кого-небудь' [Фразеологічний словник української мови 1999, 2: 764]. Спростимо визначення. У більшості людей головною (важливою) $є$ права рука. Тому правою рукою називають людину, яка $є$ важливою для когось, якій довіряють. Варто порівняти з висловом ліва рука, ліворукий (криворукий). Загальновідомо, що шульга 'той, хто лівою рукою володіє краще, ніж правою' [Словник української мови 1971-1980, 4: 508]. Однак інколи шульгою (лівшею) можуть назвати людину, яка не вміє чогось робити добре, має “криві або ліві руки”. У переносному значенні простежуємо образливу конотацію.

Їхати зайцем (зайчиком). Цей фразеологізм поширений у мовленні, оскільки студенти переважно користуються громадським транспортом. Проїзд у транспорті коштує певну суму. “Зайчиками”, як відомо, називають людей, які не заплатили за проїзд. Можливо, іноземні студенти також інколи можуть відчувати себе зайцями.

Загальновідомо, що основою величезної кількості вірувань і обрядів $\epsilon$ фізіологічні стадії людського життя, найперше - пов'язані з його переломними моментами: одруженням, народженням і хрестинами дитини, смертю та ін. У цих традиціях, звичаях знайшли своє відображення фразеологізми зустрічати хлібом-сіллю; посилати по рушники; покривати голову.

Покривати голову - 'одружуватися 3 ким-небудь' [Фразеологічний словник української мови 1999, 2: 667]. За українським звичаєм на весіллі мати нареченого покриває голову нареченої хусткою, що символізує заміжжя дівчини. Наречена 3 дівчини стає дружиною, жінкою чоловіка. Цей фразеологізм демонструє українські традиції.

Hi nари з рота не пустити - 'мовчати, не сказати жодного слова' [Коломієць, Регушевський 1988: 71]. Цей фразеологізм можна подати візуально. Викладач просто закриває рот рукою. Так він нічого не може сказати.

Позбавити життя, збавляти життя - 'убивати, губити кого-небудь' [Фразеологічний словник української мови 1999, 1: 322]. Словникове визначення $€$ важким для сприйняття студентами. Уважаємо за доцільне дати легше тлумачення, сформульоване з простих слів, з якими студенти знайомі. Отже, позбавити життя, збавляти життя - це 'убивати когось'. У процесі вивчення української мови іноземні студенти знайомляться з новими лексемами. Серед них є і слова життя, смерть, убивати.

Tільки душа в тілі — 'хто-небудь дуже бідний, убогий' [Фразеологічний словник української мови 1999, 1: 282]. Саме душа, а не тіло людини, створена за образом Божим. Тіло - це лише оселя душі. Душа - внутрішній, 
психологічний світ людини. Бідний, бідність порівнюється з душею, адже душа - це найцінніше і єдине, що людина має, крім власної душі людина більше нічого не має, іiї не можна купити.

Тільки шкіра та кістки - 'дуже худий'. На заняттях української мови як іноземної студенти вивчають принципи опису зовнішності людини. Для кращого засвоєння матеріалу можна використати антонім худий-товстий.

Спати мов убитий - 'дуже міцно, непробудно спати'. Можна використати власний досвід. Часто студенти рано встають, пізно лягають спати, приходять утомлені й засинають так, що не чують дзвінка будильника. Лексему убитий можна порівняти зі словом мертвий. Адже мертві вже не прокидаються, сплять “мертвим сном".

Уважаємо за доцільне подати власні критерії відбирання фразеологічних одиниць для навчання студентів-іноземців на початковому рівні: 1) проста будова фразеологізму (слова в прямому значенні, 2-3 компоненти, проста морфемна структура); 2) прозора внутрішня форма (мотивація); 3) наявність країнознавчої інформації; 4) частотність уживання.

Фразеологізми наповнюють мовлення глибинною свіжістю, надають йому художнього звучання, лексичної й синтаксичної витонченості, довершеності. У процесі навчання викладач має сформувати мовно-комунікативний потенціал, що насамперед підвищить можливості студента ефективно сприймати й засвоювати інформацію, та звернути увагу на такі критерії: лінгвокраїнознавча та комунікативна цінність, пов'язаність із граматичним і лексичним мінімумами, можливість витлумачити фразему стисло й знайомими словами, прозора внутрішня форма, наявність відповідника в рідній мові, орієнтація на сучасну дійсність, частотність уживання фразеологізму.

Наголосімо, що навчання мови формує не лише лінгвістичну компетенцію, а й знайомить 3 культурно-національним складником для правильного сприйняття нового середовища, оскільки саме так у студента формується мовна свідомість, що полегшує сприйняття мовних формул на тлі загальних культурно-національних особливостей.

\section{Список використаної літератури}

Ажнюк Б., Англійські фразеологізми з власне іменним компонентом, [в:] „Мовознавство”, 1984, № 6, c. 61-65.

Гумбольдт В. фон., Об изучении языков, или план систематической энцииллопедии всех языков, [в:] Его же, Язык и философия культуры, пер. с нем., Москва: Прогресс, 1985, с. $346-349$.

Демський М., Украӥнські фраземи й особливості їх творення, Львів: Просвіта, 1994. Коломієць М., Регушевський Є., Словник фразеологічних синонімів, ред. В. Винник, Київ: Радянська школа, 1988. 
Кузь Г., До проблеми фразеологічного мінімуму, [в:] „Теорія і практика викладання української мови як іноземної”, 2013, вип. 8, с. 122-129.

Кузь Г., Фразеологія у підручниках з украӥнськой мови як іноземної: кількісні, якісні та дидактичні параметри, [в:] „Teka Kom. Pol.-Ukr. Związ. Kult”, 2016, с. 86-91.

Сагата Ю., Анімалістична фразеологія у вивченні мови як іноземної, [в:] „Теорія і практика викладання української мови як іноземної”, 2009, вип. 4, с. 157-171.

Селівестрова Л., Лінгвістична та психологічна основа навчання української мови як іноземної, [в:] „Теорія і практика викладання української мови як іноземної”, 2007, вип. 2, c. $8-13$.

Скиба Н., Формування комунікативної компетенції у студентів-іноземців на фразеологічному рівні (на матеріалі новітньої художньої прози), [в:] Українська мова у свіmi: зб. матер. II Міжнар. наук.-практ. конф. (Львів, 8-9 лист. 2012 р.), Львів: Вид-во Львівської політехніки, 2012, с. 268-274.

Словник украӥнської мови, в 11 томах, ред. І. К. Білодід, Київ: Наукова думка, 1973, т. 4. Украӥнська мова: Енциклопедія, ред. В. М. Русанівський, О. О. Тараненко, М. П. Зяблюк та ін., Київ: Українська енциклопедія ім. М. П. Бажана, 2004.

Філь Г., Національно-культурна конотація фразеологічних одиниць української мови, [в:] „Рідне слово в етнокультурному вимірі”, 2012, с. 267-271.

Фразеологічний словник украӥнської мови, уклад. В.М.Білоноженко, В. О. Винник, I. С. Гнатюк, В. Й. Горобець, Київ: Наукова думка, 1999, кн. 1.

Фразеологічний словник украӥнської мови, уклад. В.М.Білоноженко, В. О. Винник, I. С. Гнатюк, В. Й. Горобець, Київ: Наукова думка, 1999, кн. 2.

Шклярська М., Мовні звороти в італійській мові - сутність та проблеми викладання, [в:] Сдність навчання і наукових досліджень - головний принцип університету, зб. наук. пр. звіт.-наук. конф. викл. ун-ту за 2011 р., ч. 2, укл. Г.І. Волинка, О. В. Уваркіна, О.П. Симоненко, О.П. Смельянова, Київ: Нац. пед. ун-т ім. М. П. Драгоманова, 2012, с. 251-252.

Ядловська Н., Фразеологічний матеріал української мови в чужомовній аудиторії, [в:] „Теорія і практика викладання української мови як іноземної”, 2007, вип. 2, с. 122 125.

\section{Spysok vykorystanoi literatury [References]}

Azhnuik B., Anhliiski frazeolohizmy z vlasne imennym komponentom [English Phraseologisms with Their Own Name Component], [v:] „Movoznavstvo”, 1984, № 6, s. 61-65.

Humboldt V. fon, Ob izuchenii yazykov, ili plan sistematicheskoj e'nciklopedii vsex yazykov [On Learning Languages, or a Systematic Encyclopedia Plan for All Languages], [v:] Ego zhe, Yazyk i filosofiya kul'tury, per. s nem., Moskva: Progress, 1985, s. 346-349.

Demskyi M., Ukrainski frazemy y osoblyvosti yikh tvorennia [Ukrainian Phrases and Peculiarities of Their Creation], Lviv: Prosvita, 1994. 
Kolomiiets M., Rehushevskyi Ye., Slovnyk frazeolohichnykh synonimiv [Slovnyk Frazeolohichnykh Synonimiv], red. V. Vynnyk, Kyiv: Radianska shkola, 1988.

Kuz H., Do problemy frazeolohichnoho minimumu [The Problem of the Phraseological Minimum], [v:] „Teoriia i praktyka vykladannia ukrainskoi movy yak inozemnoi”, 2013, vyp. 8, s. 122-129.

Kuz H., Frazeolohiia u pidruchnykakh z ukrainskoi movy yak inozemnoi: kilkisni, yakisni ta dydaktychni parametry [Phraseology in Textbooks on Ukrainian as a Foreign Language: Quantitative, Qualitative and Didactic Parameters], [v:] „Teka Kom. Pol.-Ukr. Związ. Kult", 2016, s. 86-91.

Sahata Yu., Animalistychna frazeolohiia u vyvchenni movy yak inozemnoi [Animalistic Phraseology in Learning Language as Foreign One], [v:] ,Teoriia i praktyka vykladannia ukrainskoi movy yak inozemnoi”, 2009, vyp. 4, s. 157-171.

Selivestrova L., Linhvistychna ta psykholohichna osnova navchannia ukrainskoi movy yak inozemnoi [Linguistic and Psychological Basis of Teaching Ukrainian as a Foreign Language], [v:] ,Teoriia i praktyka vykladannia ukrainskoi movy yak inozemnoi”, 2007, vyp. 2, s. 8-13.

Skyba N., Formuvannia komunikatyvnoi kompetentsii u studentiv-inozemtsiv na frazeolohichnomu rivni (na materiali novitnoi khudozhnoi prozy) [Formation of Communicative Competence Among Foreign Students at the Phraseological Level (on the Material of the Latest Artistic Prose)], [v:] Ukrainska mova u sviti: zb. mater. II Mizhnar. nauk.-prakt. konf., Lviv: Vyd-vo Lvivskoi politekhniky, 2012, s. 268-274.

Slovnyk ukrainskoi movy [The Ukrainian Language Dictionary], v 11 tomakh, red. I. K. Bilodid, Kyiv: Naukova dumka, 1973, t. 4.

Ukrainska mova: Entsyklopediia [Ukrainian Language: Encyclopedia], redkol.: V. M. Rusanivskyi, O. O. Taranenko, M. P. Ziabliuk ta in., Kyiv: Ukrainska entsyklopediia im. M. P. Bazhana, 2004.

Fil H., Natsionalno-kulturna konotatsiia frazeolohichnykh odynyts ukrainskoi movy [National Cultural Connotation of Phraseological Units of the Ukrainian Language], [v:] „Ridne slovo v etnokulturnomu vymiri”, 2012, s. 267-271.

Frazeolohichnyi slovnyk ukrainskoi movy [The Phraseological Dictionary of the Ukrainian Language], uklad.: V. M. Bilonozhenko, V. O. Vynnyk, I. S. Hnatiuk, V. Y. Horobets, Kyiv: Naukova dumka, 1999, kn. 1.

Frazeolohichnyi slovnyk ukrainskoi movy [The Phraseological Dictionary of the Ukrainian Language], uklad.: V. M. Bilonozhenko, V. O. Vynnyk, I. S. Hnatiuk, V. Y. Horobets, Kyiv: Naukova dumka, 1999, kn. 2.

Shkliarska M., Movni zvoroty v italiiskii movi - sutnist ta problemy vykladannia [Language Translations in Italian — Essence and Problems of Teaching], [v:] Yednist navchannia $i$ naukovykh doslidzhen - holovnyi pryntsyp universytetu, zb. nauk. pr. zvit.-nauk. konf. vykl. un-tu za 2011 r., ch. 2, uklad. H. I Volynka, O. V. Uvarkina, O.P. Symonenko, O. P. Yemelianova, Kyiv: Nat. ped. un-t im. M. P. Drahomanova, 2012, s. 251-252.

Yadlovska N., Frazeolohichnyi material ukrainskoi movy $v$ chuzhomovnii audytorii [Phraseological Material of the Ukrainian Language in a Stranger's Audience], [v:] „Teoriia i praktyka vykladannia ukrainskoi movy yak inozemnoi”, 2007, vyp. 2, s. 122125. 